\section{(O) OPEN ACCESS}

\title{
The long-term safety and efficacy of bilateral transplantation of human fetal striatal tissue in patients with mild to moderate Huntington's disease
}

\author{
Roger A Barker, ${ }^{1,2}$ Sarah L Mason, ${ }^{1}$ Timothy P Harrower, ${ }^{1,2}$ Rachel A Swain, ${ }^{1}$ \\ Aileen K Ho, ${ }^{1}$ Barbara J Sahakian, ${ }^{4}$ Raj Mathur, Sohier Elneil, ${ }^{5}$ Steven Thornton, ${ }^{5}$ \\ Carrie Hurrelbrink, ${ }^{1}$ Richard J Armstrong, ${ }^{1}$ Pam Tyers, ${ }^{1}$ Emma Smith, ${ }^{1}$ \\ Adrian Carpenter, ${ }^{3}$ Paola Piccini, ${ }^{6}$ Yen F Tai, ${ }^{6}$ David J Brooks, ${ }^{6}$ Nicola Pavese, ${ }^{6}$ \\ Colin Watts, ${ }^{1,3}$ John D Pickard, ${ }^{1,3}$ Anne E Rosser, ${ }^{1,7}$ Stephen B Dunnett, ${ }^{1,7}$ \\ the NEST-UK collaboration
}

- Additional material is published online only. To view please visit the journal online (http://dx.doi.org/10.1136/ jnnp-2012-302441).

For numbered affiliations see end of article.

\section{Correspondence to} Dr Roger Barker, Cambridge Centre for Brain Repair, University of Cambridge, Forvie Site, Cambridge CB2 OPY, UK; rab46@cam.ac.uk

RAB and SLM joint first authors.

Received 26 April 2012 Revised 18 September 2012 Accepted 18 December 2012 Published Online First 23 January 2013

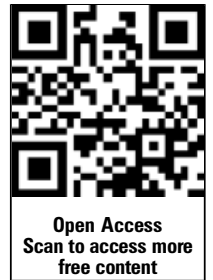

To cite: Barker RA, Mason SL, Harrower TP, et al. I Neurol Neurosurg Psychiatry 2013;84: 657-665.

\section{ABSTRACT}

Huntington's disease (HD) is a fatal autosomal dominant neurodegenerative disease involving progressive motor, cognitive and behavioural decline, leading to death approximately 20 years after motor onset. The disease is characterised pathologically by an early and progressive striatal neuronal cell loss and atrophy, which has provided the rationale for first clinical trials of neural repair using fetal striatal cell transplantation. Between 2000 and 2003, the 'NEST-UK' consortium carried out bilateral striatal transplants of human fetal striatal tissue in five HD patients. This paper describes the long-term follow up over a 3-10-year postoperative period of the patients, grafted and non-grafted, recruited to this cohort using the 'Core assessment program for intracerebral transplantations-HD' assessment protocol. No significant differences were found over time between the patients, grafted and non-grafted, on any subscore of the Unified Huntington's Disease Rating Scale, nor on the Mini Mental State Examination. There was a trend towards a slowing of progression on some timed motor tasks in four of the five patients with transplants, but overall, the trial showed no significant benefit of striatal allografts in comparison with a reference cohort of patients without grafts. Importantly, no significant adverse or placebo effects were seen. Notably, the raclopride positron emission tomography (PET) signal in individuals with transplants, indicated that there was no obvious surviving striatal graft tissue. This study concludes that fetal striatal allografting in HD is safe. While no sustained functional benefit was seen, we conclude that this may relate to the small amount of tissue that was grafted in this safety study compared with other reports of more successful transplants in patients with HD.

\section{INTRODUCTION}

Huntington's disease (HD) is an inherited, progressive neurodegenerative disorder characterised by involuntary movements, psychiatric and cognitive symptoms and signs. It is caused by an expansion of the CAG repeat in exon 1 of the huntingtin $(b t t)$ gene. Patients with 36 or more CAG repeats in this gene develop HD. Htt is now recognised to be involved in a variety of cellular, metabolic, transcription and maintenance processes throughout development and in the adult. ${ }^{12}$ Abnormal CAG expansion in HD results in neuronal dysfunction, aberrant intracellular aggregation of mutant protein fragments and, eventually, cell death. Cellular dysfunction and loss is regionally specific within the brain, with early prominent atrophy occurring within the caudate nucleus and putamen, as well as the neocortex, and eventually extending to additional areas of the brain with advancing disease. ${ }^{3}$ The condition is currently incurable with the patient usually dying within 15-30 years of disease onset. ${ }^{45}$

Current therapies provide only partial relief of some of the symptoms of HD, and no diseasemodifying therapies are yet available. One experimental therapeutic strategy has been to seek to replace the damaged and dying cells of the striatum with fetal striatal transplants, with some benefits reported in initial small studies. ${ }^{6-8}$ These studies reported motor and cognitive improvements and stabilisation over 5-6 years, consistent with data from positron emission tomography (PET) scans showing striatal metabolic activity at the site of graft placement. $^{7-10}$ However, improvement has not been consistent in all studies, and the safety of such transplants, at least in patients with advanced disease, has been questioned ${ }^{11}{ }^{12}$ (see refs ${ }^{13}$ and ${ }^{14}$ for discussion).

The NEST-UK multicentre study was initiated in 1998 as the second of two European centres to evaluate the safety and efficacy of bilateral fetal striatal transplantation in HD (ISRCTN no 36485475). ${ }^{15}$ This pilot study was designed to evaluate the feasibility, as well as providing preliminary data on the tolerability, of serial bilateral striatal transplantation in 10 patients with mild HD. The study was designed as a learning rather than a confirming trial and, as such, sought to describe what was seen, rather than being powered to show an effect. In this last issue, a confirmatory study would need to be much larger as our study only has an effect size of 0.74 , so is not (and was not intended to be) powered to formally assess efficacy. If the trial had been designed for this purpose, then 
a further 21 patients would be needed in the transplant arm to detect a clinically meaningful difference of five points on the Unified Huntington's Disease Rating Scale (UHDRS) motor scale at $10-12$ years postsurgery.

The operations were undertaken in five patients between 2000 and 2003. A preliminary report of safety of the surgical procedures has been published from the first four patients after unilateral transplantation. ${ }^{15}$ Following this, the second phase of the trial commenced, in which these patients received contralateral transplants, and one additional patient received simultaneous bilateral transplants. At that time, the European Union published the Tissue and Cells directive, ${ }^{16}$ which required that full pharmaceutical-grade standards be applied to the processing of all cells and tissues for human application, including in small academic pilot studies. Implementation of the tissue directive into UK regulation led to suspension of the NEST-UK trial, pending full compliance with the new European standards, and this process is still ongoing. Since the completion date for the original study is further extended for at least 4 years, we consider that progress in the first five patients with grafts is informative, in comparison with $12 \mathrm{HD}$ patients without grafts included in the initial cohort, and warrants an interim report, which we present here.

\section{METHODS}

Full details of the methods can be found in Rosser et al, ${ }^{15} 17$ briefly given in what follows.

\section{Patient cohort}

Initial plans for fetal cell transplantation in HD originated from the European Biomed network for striatal transplantation in HD (NEST-HD) in 1990-1993. The NEST-HD program coordinated a series of preclinical experimental studies ${ }^{18-21}$ and established a core assessment protocol for the longitudinal evaluation of patients within transplant trials (Core Assessment Program for Intracerebral Transplantations (CAPIT)-HD). ${ }^{22}$ The UK arm of

Table 1 Patient characteristics at time of recruitment

\begin{tabular}{|c|c|c|c|}
\hline Measure & Transplant & Controls & $t_{15}{ }^{*}$ \\
\hline $\mathrm{n}$ & 5 & 12 & \\
\hline Sex (M:F) & $4: 1$ & $8: 4$ & \\
\hline Age at recruitment & $43.4 \pm 1.5$ & $47.2 \pm 2.7$ & 2.11 \\
\hline Age at transplant & $48.0 \pm 1.5$ & $51.1 \pm 2.1$ & 0.88 \\
\hline Education age & $13.8 \pm 0.69$ & $12.3 \pm 0.7$ & 1.27 \\
\hline UHDRS & $23.4 \pm 6.0$ & $19.3 \pm 3.2$ & -0.87 \\
\hline Total functional assessment & $27.0 \pm 0.7$ & $26.2 \pm 0.5$ & 0.80 \\
\hline Total functional capacity & $10.4 \pm 0.8$ & $10.8 \pm 0.6$ & 0.36 \\
\hline Independence score & $94.0 \pm 1.6$ & $94.6 \pm 3.2$ & 0.11 \\
\hline Mini mental state exam & $28.8 \pm 0.3$ & $27.8 \pm 0.7$ & 0.88 \\
\hline WAIS (vocab) & $11.2 \pm 0.8$ & $10.1 \pm 0.7$ & -1.45 \\
\hline WAIS (block design) & $11.0 \pm 1.2$ & $10.7 \pm 0.7$ & -0.33 \\
\hline NART & $115.0 \pm 1.1$ & $109.6 \pm 2.1$ & $-3.19^{*}$ \\
\hline VOSP battery (total score) & $132.6 \pm 2.8$ & $129.8 \pm 3.3$ & -0.93 \\
\hline VOSP battery ( $n$ of pass) & $1.0 \pm 0.6$ & $1.3 \pm 0.4$ & 0.62 \\
\hline Boston naming test & $28.0 \pm 0.4$ & $26.8 \pm 0.4$ & -2.80 \\
\hline Token test & $33.8 \pm 0.9$ & $32.7 \pm 0.5$ & -1.53 \\
\hline
\end{tabular}

this program was established as a collaboration between six centres (NEST-UK: Belfast, Aberdeen, Manchester, Cardiff, Cambridge, London) coordinated from Cambridge, with recruitment into the longitudinal assessment cohort taking place from 1994 to 2000. Separate ethical permission for undertaking transplantation was granted in 1999 (approval number: 99/099M) to commence a clinical trial of the safety and feasibility of fetal striatal transplantation. The first five patients were all selected for grafting from the Cambridge cohort of 17 patients recruited into the CAPIT-HD longitudinal assessment program. The present report is based on 8-10 years progression in these five patients, in comparison with the 12 patients from the longitudinal cohort who were assessed as being equally suitable for transplantation, but who were not randomly selected for the surgery.

\section{Trial design}

Following discussion and endorsement with the Cambridge research ethics committee, we adopted the following patient selection protocol. Within the Cambridge cohort of 17 patients, five patients were randomly selected to receive a transplant. In 2000-2001, the first four patients received unilateral transplants of fetal striatal cells into the striatum, followed by a second transplant operation on average $22.5( \pm 3.9)$ months later into the contralateral striatum. The fifth patient received simultaneous bilateral striatal allografts in 2003. Characteristics of both the individual patients with transplants and of the reference cohort are shown in table 1. All patients have been followed longitudinally for 10 years or more using the full CAPIT-HD protocol, with 6-monthly neurological and behavioural assessments, annual neuropsychological assessments and periodic brain imaging (see below), with additional quantitative neurological and automated neuropsychological assessments (see below). All assessments were undertaken 'open label', without blinding of patients or clinicians to the treatment.

\section{Tissue preparation and neurosurgical procedures}

Full details of tissue procurement, preparation, immunosuppression, safety assessment and implantation of the first four unilateral implants has been fully reported elsewhere. ${ }^{15} 172324$ The present report is based upon the progress of these same four patients following their second, contralateral implant, and a fifth patient who received bilateral transplants in a single surgical session, following the same protocols. Surgical and donor tissue parameters are shown in table 2. Doses of the three immunosuppressant drugs were slowly withdrawn a year after the second transplant.

\section{Clinical assessment}

All patients underwent a longitudinal assessment which included the full CAPIT-HD protocol ${ }^{22}$ plus additional motor and cognitive assessments. UHDRS ${ }^{26}$ motor, functional, behavioural and cognitive scales; and the following timed motor tests, $12 \mathrm{~m}$ walking, hand tapping in $30 \mathrm{~s}^{27}$ and time to drink $120 \mathrm{ml}$ of water, were assessed at 6-month intervals: The UHDRS cognitive scale, the extended CAPIT-HD cognitive battery, and additional automated cognitive neuropsychological assessments ${ }^{28}$ were undertaken annually (see table 1). The five patients with transplants had pre- and postsurgical MRI and raclopride PET scans. ${ }^{11} \mathrm{C}$-raclopride (RAC) PET was carried out at baseline and after transplantation for 1-2 years postgrafting to assess striatal dopamine D2 receptor status and graft survival, assuming the grafts contained mature/differentiated striatal tissue which would express such receptors. ${ }^{8}$ The PET scanning protocol is as described previously. ${ }^{29}$ Six of the patients without transplants 
Table 2 Details of the right- and left-sided-placed transplants in each patient-number of fetuses/ganglionic eminences, fetal age/ stage/CRL, number of cells implanted, number and location of graft tracks in caudate and in putamen, number of deposits per track

\begin{tabular}{|c|c|c|c|c|c|}
\hline Group & Transplant & $\begin{array}{l}\text { Number } \\
\text { of } \\
\text { fetuses }\end{array}$ & $\begin{array}{l}\text { Number } \\
\text { of cells } \\
\text { (millions) }\end{array}$ & $\begin{array}{l}\text { Number } \\
\text { of tracts }\end{array}$ & $\begin{array}{l}\text { Number of } \\
\text { cells per } \\
\text { deposit per } \\
\text { tract } \\
(\text { per } \mu l)\end{array}$ \\
\hline \multirow[t]{2}{*}{ Patient 1} & 1 & 1 & 6.59 & 6 & 94000 \\
\hline & 2 & 1 & 6.2 & 6 & 103333 \\
\hline \multirow[t]{2}{*}{ Patient 2} & 1 & 1 & 11.14 & 5 & 139250 \\
\hline & 2 & 1.5 & 12.2 & 6 & 203000 \\
\hline \multirow[t]{2}{*}{ Patient 3} & 1 & 1 & 6.1 & 4 & $\begin{array}{l}\text { Not } \\
\text { recorded }\end{array}$ \\
\hline & 2 & 1 & $6 \mathrm{~m}$ & 6 & 100000 \\
\hline \multirow[t]{2}{*}{ Patient 4} & 1 & 1 & $7.1 \mathrm{~m}$ & 5 & 101429 \\
\hline & 2 & 1 & $12.2 \mathrm{~m}$ & 6 & 203333 \\
\hline Patient 5 & 1 and 2 & 2 & $5.9 \mathrm{~m}$ & 6 & 99375 \\
\hline
\end{tabular}

also received RAC PET and acted as the controls for the patients with transplants.

Most patients have been assessed over $10-15$ years; $3-5$ years prior to and 7-10 years following the transplant selection period. Full details of all tests are provided in both the supplementary materials (information about participants drug regimes (see online supplementary table S1), psychiatric assessment and automated neuropsychological assessment on the CANTAB testing battery (see online supplementary table S2) and in the methods section.

\section{Statistical analyses}

The five patients with transplants are compared with the remaining 12 patients recruited into the longitudinal NEST-HD cohort, and similarly available for selection for transplantation prior to trial suspension ('Reference control group'). Surgery in the patients with transplants was undertaken approximately 4-5 years following recruitment into the programme and all longitudinal data is referenced to the date of first transplantation $(=\mathrm{T} 0)$. The patients selected for transplant surgery were slightly younger with higher UHDRS motor scores than the remainder of the reference group at the time of first recruitment, although these differences were not significant (table 3). The only significant difference between the two groups was the National Adult Reading Test (NART) scores which suggested that the group with transplants had slightly higher premorbid IQ (table $1, \mathrm{t}_{15}=3.11, \mathrm{p}<0.01$ ), but with no correction for multiple comparisons.

For longitudinal analysis of progression in control patients, T0 was designated as 4 years following first recruitment into the programme (although other arbitrary time shifts have no effect on the results).

According to the CAPIT protocol, neurological assessments were undertaken at 6-monthly intervals, and neuropsychological assessments at yearly intervals, although there were inevitably small variations in the precise scheduling of tests, and occasional missed assessments (less than 5\% overall). For purposes of analysis, the scores on each test were averaged for each patient in 2 -year blocks over 12 years, referenced with regard to $>2$ years pre-T0, 2-0 years prior to T0, and in 2-year blocks up to 68 years following T0. Longitudinal progression of impairments on each neurological and neuropsychological test was analysed by a two-factor analyses of variance (Genstat v.11, VSN International, Hemel Hempstead). Missing values were entered in the dataset for patients who died or withdrew before the end of the 12-year assessment window, or where consecutive tests were omitted. The Genstat analysis programme is powered to estimate missing values by an iterative minimum variance routine that reduces the degrees of freedom in the estimates of error variance to correct for regression towards the mean, allowing unbiased inclusion of all patients' data.

\section{RESULTS}

\section{Demographics: adverse events}

There were no major adverse events, in line with the initial safety report on the first four patients receiving unilateral transplants of fetal striatal tissue. ${ }^{15}$

The patients all showed a transient and anticipated decline in renal function post-transplantation, secondary to the cyclosporine immunotherapy they were receiving. This resolved when the treatment was eventually discontinued. Immunosuppression was also thought to be responsible for a transient anaemia in Patients 1 and 3, which again resolved on stopping the medication.

Soon after the second transplant, Patient 3 experienced a problem with lumbar disc disease, but this spontaneously resolved without recourse to surgery.

Table 3 Demographics of patients, grafted and non-grafted. The table shows the age at time of operation (for patients without grafts, the time of surgery is taken as May of the year 2000; which is the average date of the operations of the first four patients) along with their disease characteristics

\begin{tabular}{|c|c|c|c|c|c|c|}
\hline Group & Age & $\begin{array}{l}\text { M: } \\
\text { F }\end{array}$ & $\begin{array}{l}\text { Duration of disease at time } \\
\text { of first surgery (years) }\end{array}$ & $\begin{array}{l}\text { Duration of disease at } \\
\text { last assessment }\end{array}$ & $\begin{array}{l}\text { UHDRS total motor } \\
\text { score at surgery }\end{array}$ & $\begin{array}{l}\text { Last recorded UHDRS total motor } \\
\text { score (months after first graft) }\end{array}$ \\
\hline Patient 1 & 50 & $\mathrm{~F}$ & 7 & 17 & 31 & 37 (120 mo) \\
\hline Patient 2 & 52 & $M$ & 9 & 15 & 46 & 58 (108 mo) \\
\hline Patient 3 & 53 & $M$ & 7 & 16 & 32 & 66 (96 mo) \\
\hline Patient 4 & 45 & $M$ & 6 & 15 & 78 & 87 (36mo) \\
\hline Patient 5 & 44 & $\mathrm{M}$ & 4 & 10 & 12 & 25 (78 mo) \\
\hline $\begin{array}{l}\text { Patients with grafts } \\
\text { average }\end{array}$ & $\begin{array}{l}48.8 \\
\pm 14.6\end{array}$ & $\begin{array}{l}4: \\
1\end{array}$ & $6.6 \pm 0.8$ & $14.6 \pm 1.2$ & $39.8 \pm 10.9$ & $54.6 \pm 10.9$ \\
\hline $\begin{array}{l}\text { Patients } \\
\text { withoutgrafts average }\end{array}$ & $\begin{array}{l}49.8 \\
\pm 2.02\end{array}$ & $\begin{array}{l}8: \\
4\end{array}$ & $7.2 \pm 2.4$ & $14.9 \pm 3.5$ & $27.9 \pm 14.0$ & $40.5 \pm 19.7$ \\
\hline
\end{tabular}


Patient 1 developed a renal cell carcinoma following the first transplant which was resected with no residual tumour and no metastatic spread. The occurrence of this tumour was thought to be unrelated to either the transplant or immunosuppressive medication, and as such, the patient completed a full course of immunosuppression following the second transplant without any adverse events.

\section{Clinical assessment}

An average of 22.5 months after the first transplant, patients 1, 2,3 and 4 had a second transplant to the contralateral striatum. The first three of these patients then continued to attend for regular assessments for the next 5 years. Patient 4 was unable to attend further appointments after 2005, 2 years after his second transplant. He died on 25 December 2009; the cause of death was recorded as aspiration pneumonia. No postmortem was conducted, nor unfortunately, was the brain collected for analysis. Patient five received a bilateral transplant and is still being followed-up 6 years after his operation. Details of drug treatments and performance on assessments additional to the CAPIT-HD protocol are included in the supplementary data.

\section{Motor assessments}

\section{UHDRS total motor score}

The total UHDRS motor score of the five patients with transplants was compared with that of the 12 patients without grafts. Over a 13-year follow-up, the UHDRS score increased progressively in all patients, signifying a slow progressive worsening of motor signs (figure 1). The best fit regression lines to the annual means of each group indicated a highly significant rate of disease progression in both groups (Transplant, $r=0.628$, $\mathrm{t}_{12}=2.80, \mathrm{p}<0.02$; Reference controls, $\mathrm{r}=0.708, \mathrm{t}_{12}=3.47$. $\mathrm{p}<0.01$ ), and the slopes of the best regression fits in the two groups did not differ.

Analysis of individual patients revealed some apparent improvements. Thus, Patient 1 showed improvement after the first unilateral transplant, with the UHDRS motor score falling from 37 to 18 in the first 6 months after transplantation. After the second transplant, (at $\mathrm{T}=22.5$ on the graph) the UHDRS motor scores became and continued to get progressively worse. The final UHDRS score recorded 10 years after the first transplant was 37. This patient has never received any drug treatment for her chorea. Patient 2 also improved his motor score after the first transplant and again after the second operation, and for the next 6 years their motor UHDRS score seemed to stabilise. Motor scores, however, then deteriorated and have continued to do so to the present time, and olanzapine was started for psychiatric problems 7 years after the initial transplant. However, some individual patients in the reference control group showed equally marked improvements at particular points during the course of their 6-monthly, or annual assessments (see figure 1). Thus, we see no evidence when comparing all patients of the two groups of a significant short-term improvement following transplantation, and no evidence for a change of slope of disease progression. Importantly, there is also no evidence of a detectable placebo effect in the transplant group when using objective motor ratings in the UHDRS, even though this is an open label trial design.

\section{Full CAPIT neurological assessment}

Neurological assessments were conducted at 6-monthly intervals according to the CAPIT protocol. For purposes of analysis, the scores on each test were averaged for each patient in 2-year blocks over 12 years, referenced with regard to $>2$ years pre-T0,

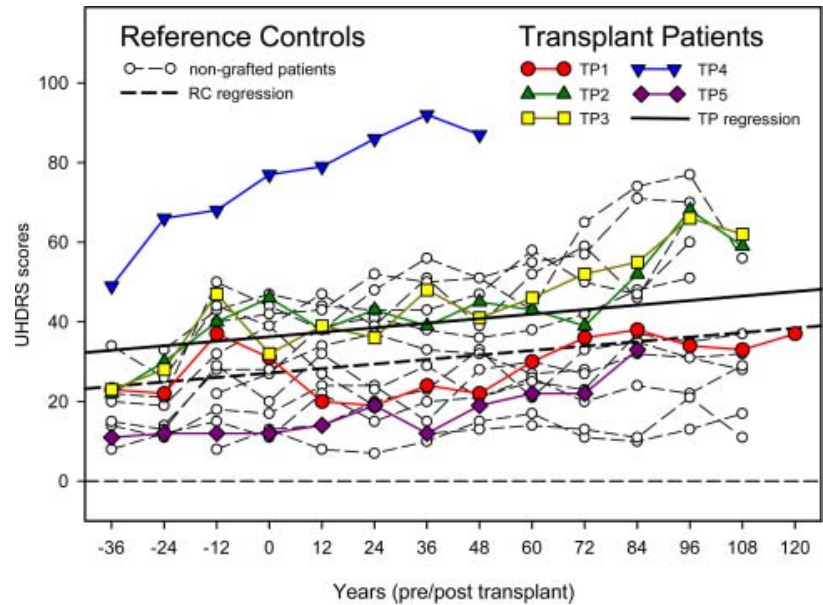

Figure 1 Annual Unified Huntington's Disease Rating Scale total motor scores from 3 years prior to and up to 10 years following the time of the first transplant surgery in the five patients with grafts, and in the 12 reference control patients synchronised with the stage at which they would have received transplants if the programme had been able to continue. *The first four transplant cases (TP1-4) received serial transplant surgeries on the two sides at times $\mathrm{T} 1$ and $\mathrm{T} 2$ separated by approximately 2 years, whereas TP5 received a single bilateral surgery at T1. The bold line indicates the best fit linear regression applied to the five transplant cases (solid) and separately to the 12 controls (dashed). Note that the separation between the two lines is fully attributable to the one transplant case TP4, whose Unified Huntington's Disease Rating Scale scores were significantly higher than any other case in the cohort, whereas the slope of the two regression lines, indicating rate of disease progression in the two groups, do not differ.

2-0 years prior to T0, and in 2-year blocks up to 6-8 years following T0. As shown in table 4, all test measures showed a clear and very highly significant (Years, $\mathrm{F}_{5,69}=6.20-39.31$, all $\mathrm{p}<0.001$ ) worsening over time. However, none of the tests showed any difference between the transplant and reference control groups, either overall, nor following transplant surgery, with the sole exception of the timed walk subtest, in which the interaction term reached significance if no correction is made for multiple testing (Groups $\times$ Years, $\mathrm{F}_{5,69}=2.67, \mathrm{p}<0.05$ ). However, although it does appear that the group with transplants shows a slowing of impairment on this one test, the only significant difference relates to the last time point $10-12$ years after initial recruitment $6-8$ years postsurgery, and not in the period immediately following transplantation.

\section{Full CAPIT neuropsychological assessment}

Progression of performance in the neuropsychological test battery was similarly analysed, combining each patient's mean performance in 2-year blocks. As shown in table 5, and similar to the neurological measures, 20 of the 21 tests showed highly significant progression over the 12 years of repeated assessments (Years, $\mathrm{F}_{5,69}=4.63-44.63$, all $\mathrm{p}<0.001$ ), the only exception being the Rivermead test of recognition memory, which showed very little impairment in either group even in the advanced patients. Again, none of the tests showed any significant differences between patients with transplants and reference controls, either overall or in terms of a differential response following transplantation, with the sole exception of the categories submeasure of the Wisconsin Card Sorting test, on which the remaining patients with transplants showed differentially poorer performance on the final test 6-8 years postsurgery 
Table 4 CAPIT UHDRS and motor assessments

\begin{tabular}{|c|c|c|c|c|c|c|c|c|c|c|}
\hline Tests & Years & $\begin{array}{l}0-2 \text { years } \\
\text { (2-4 years } \\
\text { pre-T1) } \\
\text { Mean } \pm S E M\end{array}$ & $\begin{array}{l}\text { 2-4 years } \\
\text { (0-2 years } \\
\text { pre-T0) } \\
\text { Mean } \pm \text { SEM }\end{array}$ & $\begin{array}{l}\text { 4-6 years } \\
(0-2 \text { years } \\
\text { post-T0) } \\
\text { Mean } \pm S E M\end{array}$ & $\begin{array}{l}6-8 \text { years } \\
(2-4 \text { years } \\
\text { post-T0) } \\
\text { Mean } \pm S E M\end{array}$ & $\begin{array}{l}\text { 8-10 years } \\
\text { (4-6 years } \\
\text { post-T0) } \\
\text { Mean } \pm S E M\end{array}$ & $\begin{array}{l}10-12 \text { years } \\
(6-8 \text { years } \\
\text { post-T0) } \\
\text { Mean } \pm S E M\end{array}$ & $\begin{array}{l}\text { Groups } \\
F_{1,15}\end{array}$ & $\begin{array}{l}\text { Time } \\
F_{5,69}\end{array}$ & $\begin{array}{l}\text { Group } \times \text { Time } \\
F_{5,69}\end{array}$ \\
\hline \multirow{2}{*}{$\begin{array}{l}\text { UHDRS (total } \\
\text { motor scale) }\end{array}$} & Control & $20.3 \pm 3.2$ & $27.9 \pm 3.8$ & $32.4 \pm 3.8$ & $33.3 \pm 3.9$ & $37.4 \pm 5.7$ & $42.1 \pm 6.8$ & 1.16 & 26.38 * * & 0.87 \\
\hline & Transplant & $26.3 \pm 7.2$ & $39.0 \pm 9.7$ & $38.7 \pm 11.1$ & $44.2 \pm 12.3$ & $35.8 \pm 5.4$ & $46.0 \pm 7.9$ & & & \\
\hline \multirow{2}{*}{$\begin{array}{l}\text { UHDRS (functional } \\
\text { assessment) }\end{array}$} & Control & $14.1 \pm 2.5$ & $19.7 \pm 2.9$ & $21.7 \pm 2.5$ & $22.4 \pm 2.8$ & $27.4 \pm 4.7$ & $32.8 \pm 6.0$ & 1.00 & 14.80 ** & 0.62 \\
\hline & Transplant & $19.5 \pm 5.0$ & $28.0 \pm 8.1$ & $27.3 \pm 10.4$ & $31.6 \pm 12.8$ & $22.7 \pm 5.9$ & $35.3 \pm 9.1$ & & & \\
\hline \multirow{2}{*}{$\begin{array}{l}\text { UHDRS (ADL } \\
\text { scale) }\end{array}$} & Control & $23.6 \pm 0.6$ & $22.5 \pm 0.9$ & $21.9 \pm 1.0$ & $19.9 \pm 1.5$ & $17.3 \pm 2.3$ & $16.4 \pm 3.0$ & 0.15 & 12.37 * * & 0.47 \\
\hline & Transplant & $23.2 \pm 0.9$ & $22.3 \pm 1.0$ & $22.1 \pm 0.8$ & $18.0 \pm 3.1$ & $18.4 \pm 2.2$ & $14.3 \pm 3.5$ & & & \\
\hline \multirow{2}{*}{$\begin{array}{l}\text { UHDRS } \\
\text { (independence } \\
\text { scale) }\end{array}$} & Control & $92.4 \pm 2.9$ & $86.6 \pm 3.2$ & $83.2 \pm 3.0$ & $77.8 \pm 3.1$ & $72.5 \pm 4.7$ & $66.6 \pm 6.1$ & 0.23 & 26.14 ** & 0.43 \\
\hline & Transplant & $91.7 \pm 3.9$ & $85.6 \pm 3.9$ & $83.1 \pm 3.6$ & $72.8 \pm 8.1$ & $72.6 \pm 4.3$ & $63.9 \pm 7.1$ & & & \\
\hline \multirow[t]{2}{*}{ Fahn score } & Control & $10.37 \pm 0.76$ & $9.62 \pm 0.79$ & $8.97 \pm 0.77$ & $7.97 \pm 0.94$ & $6.99 \pm 1.09$ & $6.07 \pm 1.33$ & 0.44 & $15.42 * *$ & 0.28 \\
\hline & Transplant & $9.68 \pm 0.98$ & $8.42 \pm 1.34$ & $8.78 \pm 0.90$ & $7.18 \pm 1.41$ & $6.08 \pm 1.43$ & $5.13 \pm 2.19$ & & & \\
\hline \multirow{2}{*}{$\begin{array}{l}\text { Cognitive battery } \\
\text { (total scores) }\end{array}$} & Control & $232 \pm 12$ & $212 \pm 13$ & $188 \pm 14$ & $165 \pm 17$ & $167 \pm 22$ & $152 \pm 27$ & 0.19 & 39.31 ** & 0.89 \\
\hline & Transplant & $220 \pm 22$ & $217 \pm 29$ & $186 \pm 28$ & $152 \pm 32$ & $159 \pm 32$ & $125 \pm 40$ & & & \\
\hline \multirow[t]{2}{*}{ Timed tests (walk) } & Control & $9.76 \pm 0.56$ & $9.81 \pm 0.30$ & $11.20 \pm 0.67$ & $11.93 \pm 0.64$ & $13.28 \pm 0.50$ & $17.30 \pm 2.84$ & 4.05 & $9.90 * *$ & $2.67^{*}$ \\
\hline & Transplant & $9.38 \pm 0.34$ & $9.98 \pm 0.47$ & $10.66 \pm 1.38$ & $10.05 \pm 1.06$ & $10.12 \pm 1.34$ & $10.40 \pm 1.57$ & & & \\
\hline \multirow{2}{*}{$\begin{array}{l}\text { Timed tests (hand } \\
\text { tap L\&R) }\end{array}$} & Control & $86.8 \pm 7.2$ & $79.4 \pm 5.4$ & $67.8 \pm 5.5$ & $60.4 \pm 4.7$ & $52.7 \pm 4.5$ & $48.4 \pm 5.3$ & 0.08 & 36.27 ** & 0.79 \\
\hline & Transplant & $82.8 \pm 10.1$ & $77.3 \pm 11.1$ & $72.8 \pm 13.0$ & $62.9 \pm 15.8$ & $68.8 \pm 15.9$ & $62.7 \pm 17.7$ & & & \\
\hline \multirow[t]{2}{*}{ Timed tests (drink) } & Control & $13.23 \pm 1.03$ & $13.29 \pm 1.90$ & $15.07 \pm 1.86$ & $19.21 \pm 3.32$ & $19.33 \pm 4.42$ & $24.30 \pm 6.83$ & 0.49 & $6.20^{* *}$ & 1.51 \\
\hline & Transplant & $5.00 \pm *$ & $10.38 \pm 2.23$ & $12.06 \pm 4.18$ & $16.96 \pm 7.28$ & $9.35 \pm 2.71$ & $11.00 \pm 4.48$ & & & \\
\hline
\end{tabular}

${ }^{* *} p<0.001 ;{ }^{*} p<0.05$ (not significant when correcting for multiple comparisons); transplant improved (+), or impaired (-) with respect to the reference controls.

UHDRS (total motor score): 0-124, 124 worse; UHDRS (functional assessment): 25-50, 50 worse; UHDRS (ADL scale): 0 worse; UHDRS (independence scale); 0-100, 0 worse,; Fahn score: $0-13,0$ worse; Cognitive battery: 0 worse; Timed tests (walk, hand tap (I \& r) and drink): 0 worse.

CAPIT, Core assessment program for intracerebral transplantations; ADL, activities of daily living; UHDRS, Unified Huntington's Disease Rating Scale.

Note: all significant results are identified in bold.

(Groups $\times$ Years, $\mathrm{F}_{5,69}=4.52, \mathrm{p}<0.001$, uncorrected for multiple comparisons). By contrast to the conventional neuropsychological tests, we found the CANTAB automated touch screen measures to be less sensitive to the longitudinal progression of the disease (see supplementary table 2).

\section{Imaging}

MRI

Postoperative MRI scans confirmed appropriate surgical targeting with increased FLAIR signal along the implantation tracts. No occult haemorrhage was identified. Subsequent imaging was unable to identify any implanted material, and there were no mass lesions seen to develop in or around the transplant site. No volumetric studies were undertaken as MRI was employed for safety assessments only. All patients continued to have increased ventricular volume after the transplants, but as we did not collect data on ventricular volume prior to transplantation, nor on patients without grafts, we cannot conclude anything further with respect to how the transplants affected striatal or whole brain atrophy.

\section{PET}

As the first four surgical subjects received implantation into the right striatum initially, their left striatal binding potential (BP) acted as an internal control for the contralateral side prior to the second implantation. Averaging the PET results of the first four subjects who received unilateral transplants, the rates of decline of striatal RAC BP were slightly higher on the right (transplanted side) after the first implantation, but this difference disappeared after the second implantation. The overall rates of progression from baseline to 1 year after the second operation were similar on both sides, and were not significantly different from those of non-grafted HD controls (figure 2), in line with previous longitudinal studies in HD using this ligand.

Subject 5 was scanned using a different PET camera and hence, his data could not be compared directly with the rest. The rates of progression of his striatal RAC BP at 1 year posttransplantation were $8.9 \%$ and $7.3 \%$ per annum for the right and left sides respectively. He did not receive further RAC PET scans as he was started on quetiapine for a psychotic episode, which interferes with RAC binding.

\section{DISCUSSION}

This study reports the long-term safety, motor, cognitive and psychiatric effects of bilateral fetal striatal allotransplants in five patients with mild to moderate HD, in comparison with a reference group of 12 patients from the same cohort who were similarly suitable for transplantation but not selected for surgery, but were followed in an identical way.

There were no significant differences in any of the measures chosen when comparing patients with transplants with this reference cohort at baseline and followed-up for up to 10 years postsurgery, using identical protocols of assessment. In small open label studies with multiple outcome measures, it is 


\begin{tabular}{|c|c|c|c|c|c|c|c|c|c|c|}
\hline Tests & Years & $\begin{array}{l}0-2 \text { years }(2-4 \text { years } \\
\text { pre-T1) } \\
\text { Mean } \pm \text { SEM }\end{array}$ & $\begin{array}{l}2-4 \text { years }(0-2 \text { years } \\
\text { pre-T1) } \\
\text { Mean } \pm \text { SEM }\end{array}$ & $\begin{array}{l}4-6 \text { years }(0-2 \text { years } \\
\text { post }-T 1) \\
\text { Mean } \pm \text { SEM }\end{array}$ & $\begin{array}{l}6-8 \text { years }(0-2 \text { years } \\
\text { post-T1) } \\
\text { Mean } \pm \text { SEM }\end{array}$ & $\begin{array}{l}8-10 \text { years }(0-2 \text { years } \\
\text { post-T1) } \\
\text { Mean } \pm \text { SEM }\end{array}$ & $\begin{array}{l}10-12 \text { years }(0-2 \text { years } \\
\text { post-T1) } \\
\text { Mean } \pm \text { SEM }\end{array}$ & $\begin{array}{l}\text { Groups } \\
F_{1,15} \\
\end{array}$ & $\begin{array}{l}\text { Time } \\
\mathrm{F}_{5,68}\end{array}$ & $\begin{array}{l}\text { Group } \times \text { Time } \\
F_{5,68}\end{array}$ \\
\hline \multirow[t]{2}{*}{ Verbal fluency (letters) } & $\begin{array}{l}\text { Control } \\
(n=12)\end{array}$ & $31.8 \pm 1.9$ & $31.3 \pm 2.1$ & $30.2 \pm 2.1$ & $27.7 \pm 3.5$ & $25.7 \pm 3.6$ & $23.9 \pm 5.5$ & 0.93 & $7.42^{* *}$ & 2.95 \\
\hline & $\begin{array}{l}\text { Transplant } \\
(\mathrm{n}=5)\end{array}$ & $299 \pm 5.2$ & $32.0 \pm 6.3$ & $27.8 \pm 5.9$ & $24.1 \pm 5.6$ & $26.4 \pm 4.1$ & $19.5 \pm 3.0$ & & & \\
\hline \multirow[t]{2}{*}{ Verbal fluency (animals) } & Control & $15.3 \pm 1.1$ & $14.5 \pm 1.1$ & $14.2 \pm 1.3$ & $11.9 \pm 1.6$ & $11.9 \pm 2.1$ & $11.9 \pm 2.4$ & 0.01 & $15.93^{* *}$ & 0.82 \\
\hline & Transplant & $18.0 \pm 0.9$ & $16.2 \pm 2.8$ & $13.1 \pm 2.2$ & $11.4 \pm 2.0$ & $10.2 \pm 1.2$ & $9.0 \pm 3.0$ & & & \\
\hline \multirow[t]{2}{*}{ Symbol digit } & Control & $34.6 \pm 3.3$ & 30.13 .2 & $27.0 \pm 3.5$ & $22.5 \pm 3.3$ & $21.7 \pm 4.6$ & $29.2 \pm 6.7$ & 0.18 & $40.18^{* *}$ & 0.49 \\
\hline & Transplant & $33.6 \pm 4.3$ & $28.9 \pm 4.4$ & $24.2 \pm 3.6$ & $21.4 \pm 5.0$ & $18.5 \pm 3.5$ & $17.8 \pm 5.9$ & & & \\
\hline \multirow[t]{2}{*}{ Stroop (colours) } & Control & $55.7 \pm 3.0$ & $48.8 \pm 2.9$ & $45.8 \pm 2.9$ & $38.4 \pm 3.5$ & $34.0 \pm 3.3$ & $33.7 \pm 5.1$ & 0.08 & $38.70^{* *}$ & 0.48 \\
\hline & Transplant & $51.8 \pm 5.0$ & $51.0 \pm 6.9$ & $44.7 \pm 7.3$ & $37.1 \pm 8.3$ & $35.5 \pm 9.3$ & $33.7 \pm 10.7$ & & & \\
\hline \multirow[t]{2}{*}{ Stroop (words) } & Control & $76.4 \pm 4.7$ & $67.7 \pm 4.9$ & $59.8 \pm 5.4$ & $50.7 \pm 5.3$ & $47.0 \pm 5.7$ & $41.3 \pm 7.3$ & 0.09 & $44.63^{* *}$ & 0.71 \\
\hline & Transplant & $70.2 \pm 6.8$ & $71.9 \pm 8.8$ & $58.9 \pm 7.8$ & $44.4 \pm 8.9$ & $45.7 \pm 10.0$ & $42.6 \pm 10.7$ & & & \\
\hline Stroop & Control & $31.1 \pm 2.1$ & $29.9 \pm 2.0$ & $26.0 \pm 1.8$ & $22.2 \pm 2.2$ & $18.5 \pm 2.7$ & $17.6 \pm 3.4$ & 0.09 & $27.44^{* *}$ & 0.54 \\
\hline (interference) & Transplant & $30.2 \pm 4.9$ & $33.2 \pm 6.5$ & $27.6 \pm 4.4$ & $23.9 \pm 6.8$ & $24.7 \pm 7.6$ & $19.5 \pm 7.0$ & & & \\
\hline \multirow{2}{*}{ MMSE } & Control & $28.1 \pm 0.5$ & $27.9 \pm 0.5$ & $27.3 \pm 0.6$ & $27.3 \pm 0.8$ & $25.7 \pm 1.3$ & $25.7 \pm 1.3$ & 0.02 & $10.98^{* *}$ & 0.57 \\
\hline & Transplant & $28.1 \pm 0.4$ & $27.9 \pm 0.7$ & $28.0 \pm 0.5$ & $27.4 \pm 0.9$ & $25.1 \pm 1.2$ & $25.5 \pm 1.8$ & & & \\
\hline \multirow[t]{2}{*}{ Hopkins (test 1) } & Control & $5.6 \pm 0.4$ & $5.7 \pm 0.5$ & $5.4 \pm 0.5$ & $4.8 \pm 0.5$ & $4.7 \pm 0.7$ & $4.7 \pm 0.9$ & 0.36 & $6.42^{* *}$ & 0.43 \\
\hline & Transplant & $5.8 \pm 0.9$ & $5.6 \pm 0.5$ & $4.5 \pm 0.4$ & $4.4 \pm 0.8$ & $3.9 \pm 0.8$ & $3.5 \pm 0.5$ & & & \\
\hline \multirow{2}{*}{ Hopkins (test 2) } & Control & $7.4 \pm 0.4$ & $7.4 \pm 0.6$ & $7.1 \pm 0.5$ & $6.7 \pm 0.6$ & $6.9 \pm 0.7$ & $6.5 \pm 1.2$ & 0.12 & $11.42^{* *}$ & 2.06 \\
\hline & Transplant & $8.3 \pm 0.9$ & $7.6 \pm 0.6$ & $6.8 \pm 1.0$ & $5.3 \pm 0.8$ & $5.7 \pm 0.5$ & $5.0 \pm 1.0$ & & & \\
\hline \multirow{2}{*}{ Hopkins (test 3) } & Control & $8.3 \pm 0.6$ & $8.7 \pm 0.7$ & $7.6 \pm 0.8$ & $7.0 \pm 0.7$ & $8.1 \pm 0.7$ & $6.6 \pm 1.7$ & 0.00 & $7.98^{* *}$ & 1.97 \\
\hline & Transplant & $8.8 \pm 0.8$ & $8.3 \pm 0.8$ & $8.1 \pm 1.0$ & $6.2 \pm 1.1$ & $6.7 \pm 0.4$ & $7.0 \pm 1.0$ & & & \\
\hline \multirow[t]{2}{*}{ Hopkins (delays) } & Control & $7.7 \pm 0.6$ & $7.7 \pm 0.8$ & $6.4 \pm 0.9$ & $5.8 \pm 1.0$ & $6.4 \pm 1.0$ & $6.3 \pm 1.5$ & 0.07 & $9.63^{* *}$ & 0.54 \\
\hline & Transplant & $8.2 \pm 0.9$ & $7.9 \pm 0.9$ & $7.2 \pm 1.4$ & $6.1 \pm 1.3$ & $5.2 \pm 0.3$ & $5.5 \pm 1.5$ & & & \\
\hline \multirow[t]{2}{*}{ WCST (categories) } & Control & $5.3 \pm 0.4$ & $5.7 \pm 0.3$ & $5.4 \pm 0.3$ & $5.4 \pm 0.3$ & $5.4 \pm 0.2$ & $5.7 \pm 0.3$ & 2.86 & $5.12^{* *}$ & $4.52^{* *}$ \\
\hline & Transplant & $4.7 \pm 0.8$ & $4.9 \pm 1.0$ & $4.6 \pm 0.9$ & $4.5 \pm 0.7$ & $4.3 \pm 1.1$ & $1.5 \pm 1.5$ & & & \\
\hline \multirow[t]{2}{*}{ WCST (errors) } & Control & $6.6 \pm 2.1$ & $6.2 \pm 1.9$ & $6.5 \pm 1.7$ & $7.9 \pm 2.2$ & $6.1 \pm 1.1$ & $4.4 \pm 2.1$ & 2.02 & $4.90^{* *}$ & $3.54^{*}$ \\
\hline & Transplant & $11.9 \pm 4.7$ & $9.0 \pm 5.6$ & $10.4 \pm 4.5$ & $13.5 \pm 4.8$ & $11.9 \pm 4.5$ & $25.5 \pm 8.5$ & & & \\
\hline \multirow[t]{2}{*}{ Trails test (form A) } & Control & $61.8 \pm 7.1$ & $58.6 \pm 5.3$ & $71.6 \pm 9.60$ & $85.9 \pm 11.6$ & $76.9 \pm 14.5$ & $72.7 \pm 17.3$ & 1.01 & $13.62^{* *}$ & 0.85 \\
\hline & Transplant & $67.5 \pm 16.7$ & $72.1 \pm 13.9$ & $88.3 \pm 20.3$ & $90.2 \pm 30.3$ & $112.2 \pm 20.6$ & $110.0 \pm 57.0$ & & & \\
\hline \multirow[t]{2}{*}{ Trails test (form B) } & Control & $118.5 \pm 12.2$ & $162.7 \pm 34.9$ & $135.7 \pm 16.6$ & $135.9 \pm 18.5$ & $155.7 \pm 29.3$ & $157.4 \pm 54.1$ & 0.48 & $10.44^{\star *}$ & 0.53 \\
\hline & Transplant & $135.4 \pm 22.1$ & $128.7 \pm 15.7$ & $227.0 \pm 97.1$ & $164.2 \pm 15.7$ & $199.7 \pm 62.3$ & $* *$ & & & \\
\hline \multirow[t]{2}{*}{ Recognition memory } & Control & $10.7 \pm 0.4$ & $10.7 \pm 0.5$ & $10.2 \pm 0.7$ & $10.7 \pm 0.4$ & $10.1 \pm 0.5$ & $10.0 \pm 0.5$ & 0.17 & 0.83 & 0.24 \\
\hline & Transplant & $11.3 \pm 0.3$ & $10.8 \pm 0.5$ & $10.7 \pm 0.5$ & $10.0 \pm 0.9$ & $10.5 \pm 0.7$ & $10.0 \pm 3.0$ & & & \\
\hline \multirow[t]{2}{*}{ Digit span (forward) } & Control & $7.4 \pm 0.3$ & $7.5 \pm 0.4$ & $7.4 \pm 0.5$ & $6.6 \pm 0.3$ & $7.1 \pm 0.5$ & $6.2 \pm 0.9$ & 0.21 & $9.03^{* *}$ & 0.97 \\
\hline & Transplant & $7.5 \pm 0.4$ & $6.6 \pm 0.4$ & $6.9 \pm 0.9$ & $6.8 \pm 0.7$ & $6.0 \pm 1.1$ & $5.8 \pm 0.8$ & & & \\
\hline \multirow[t]{2}{*}{ Digit span (backward) } & Control & $5.4 \pm 0.4$ & $4.8 \pm 0.4$ & $5.0 \pm 0.5$ & $4.6 \pm 0.5$ & $4.7 \pm 0.6$ & $4.3 \pm 0.6$ & 0.09 & $6.50^{* *}$ & 0.46 \\
\hline & Transplant & $5.5 \pm 0.5$ & $5.1 \pm 0.5$ & $5.1 \pm 0.6$ & $5.3 \pm 0.9$ & $3.5 \pm 0.8$ & $4.0 \pm 0.0$ & & & \\
\hline \multirow[t]{2}{*}{ Rivermead (immediate) } & Control & $7.4 \pm 0.3$ & $7.5 \pm 0.4$ & $7.4 \pm 0.5$ & $6.6 \pm 0.4$ & $7.1 \pm 0.5$ & $6.2 \pm 0.9$ & 0.40 & $5.91^{* *}$ & 0.82 \\
\hline & Transplant & $7.5 \pm 0.4$ & $6.6 \pm 0.4$ & $6.9 \pm 0.8$ & $6.8 \pm 0.7$ & $6.0 \pm 1.1$ & $5.8 \pm 0.8$ & & & \\
\hline \multirow[t]{2}{*}{ Rivermead (delay) } & Control & $5.4 \pm 0.4$ & $4.8 \pm 0.4$ & $5.0 \pm 0.5$ & $4.6 \pm 0.5$ & $4.7 \pm 0.6$ & $4.3 \pm 0.6$ & 0.03 & $9.42^{* *}$ & 1.83 \\
\hline & Transplant & $5.5 \pm 0.5$ & $5.1 \pm 0.5$ & $5.1 \pm 0.6$ & $5.3 \pm 0.9$ & $3.5 \pm 0.8$ & $4.0 \pm 0.0$ & & & \\
\hline \multirow[t]{2}{*}{ Conditional associates } & Control & $34.1 \pm 6.8$ & $30.1 \pm 6.0$ & $33.0 \pm 7.2$ & $39.3 \pm 7.2$ & $35.6 \pm 9.7$ & $26.0 \pm 11.1$ & 0.01 & $4.63^{* *}$ & 0.85 \\
\hline & Transplant & $31.8 \pm 8.2$ & $25.4 \pm 7.4$ & $31.7 \pm 9.3$ & $29.9 \pm 11.2$ & $38.6 \pm 15.1$ & $50.5 \pm 17.5$ & & & \\
\hline
\end{tabular}

${ }^{* *} \mathrm{p}<0.001 ;{ }^{*} \mathrm{p}<0.05$ (not significant when correcting for multiple comparisons); Transplant improved (+), or impaired (-) with respect to the reference controls.

For Trails test parts A and B, and conditional associates, a LOWER scores indicates a BETTER performance. For all other tests 0 is worse.

CAPIT, Core assessment program for intracerebral transplantations; MMSE, Mini Mental State Examination; WCST, Wisconsin Card Sorting Test.

Note: all significant results are identified in bold.

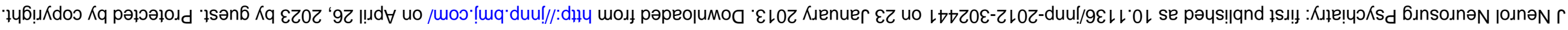


Figure 2 Mean striatal

11C-raclopride binding potential of subjects 1-4 compared with a group of the non-grafted Huntington's disease controls $(n=7)$. $T 1=$ first implantation (right-sided); $\mathrm{T} 2=$ second implantation (left-sided); BP, binding potential; R, Right; L, left. Error bars indicates SDs.

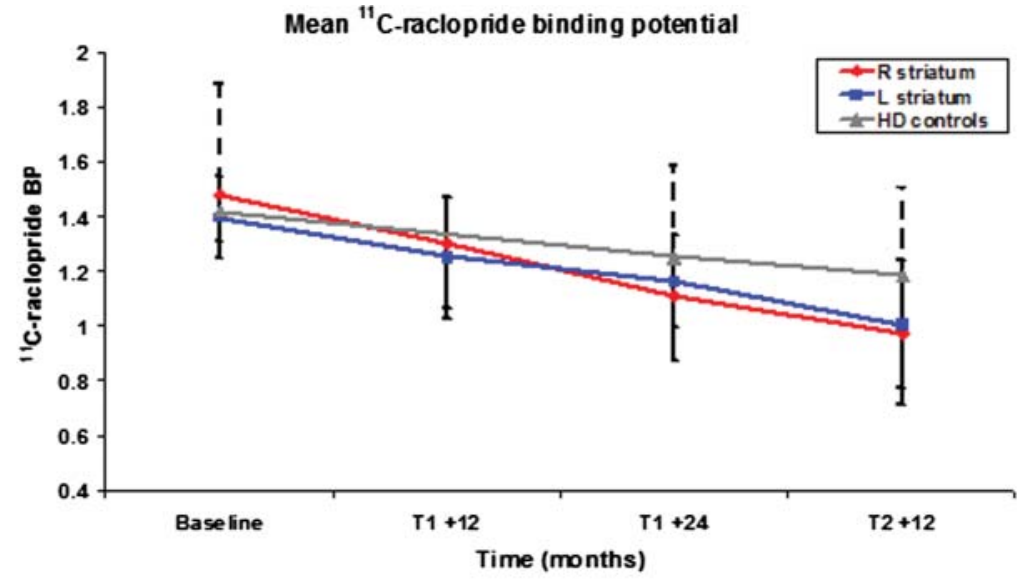

\begin{tabular}{lccc}
\hline & \multicolumn{2}{c}{ Annual \% change in ${ }^{11}$ C-raclopride binding potential } \\
\cline { 2 - 4 } & $\begin{array}{c}\text { Following right-sided } \\
\text { implantation } \\
\text { (baseline to } \mathrm{T} 1+24)\end{array}$ & $\begin{array}{c}\text { Followingleft-sided } \\
\text { implantation }\end{array}$ & $\begin{array}{c}\text { Overall rate of } \\
\text { progression } \\
\text { (baseline to } \mathrm{T} 2+12)\end{array}$ \\
\hline Right striatum & -10.5 & -9.1 & -8.8 \\
Left striatum & -6.9 & -10.3 & -7.2 \\
HD controls & - & - & -5.2
\end{tabular}

tempting to focus on apparent improvements in individual patients on particular tests. However, although such encouraging signs could be identified in the present five patients, the changes were in all cases small; similar short-term fluctuations could be identified in control patients of the reference group; and there were no statistically significant sustained improvements in the group with transplants on any of the CAPIT neurology or neuropsychology measures.

As such, the present data fails to support the efficacy of the current transplantation protocol in significantly modifying the course of patients' disease. Although one conclusion might be that cell therapy does not work in HD, this seems premature when set alongside the clear recovery observed in animal models $^{30}$ and in some patients in other studies. ${ }^{6}{ }^{8}$ It is likely that differences between the several small open label studies published to date assessing neural transplantation in HD, including the present study, relate to differences in (A) patient selection, for instance, the US study used relatively advanced patients; and (B) tissue dissection, for instance, the US study used lateral lateral ganglionic tissue grafts, whereas others have used whole striatal grafts and (C) tissue preparation, for instance, the French group used tissue pieces while we used a tissue suspension approach (for a more detailed discussion on this, see refs ${ }^{13}$ and ${ }^{14}$ ).

Alternatively, the absence of a convincing increase here in the post-transplantation striatal raclopride signal could relate more to the fact that we simply did not implant sufficient numbers of cells, a major determinant of the survival and differentiation of striatal grafts. ${ }^{31}$ A primary concern when we were first designing the NEST-UK trial was the possibility for embryonic striatal tissue to overgrow. This was first observed in some human striatal xenografts in the rat brain, ${ }^{16}$ but has also been seen in at least two clinical trials in HD patients. ${ }^{13} 3233$ In our first study of safety and feasibility, we therefore undertook implants of relatively small amounts of tissues-typically $5-10 \times 10^{6}$ cells from two or occasionally three ganglionic eminences from one or two donor embryos. The imaging results showed change in FLAIR signal along the surgical tracts consistent with minor tissue trauma. However, no significant graft deposits could be identified on serial imaging, using either MRI or RAC-PET. These observations are consistent with our previous experience with similar small graft volume protocols in rats and primates in which the implanted tissue volume was too small to exert any clear functional benefit. Rather, the dissociated cell suspension protocols employed here appear to be safe, but now warrant scaling up to implant larger numbers of cells to yield grafts of comparable size and integration to those that have been seen to be effective in animal studies. At the same time, attention still needs to be paid to accurate tissue dissection, since misdissection to include any meningeal cells can yield clear overgrowth and proliferation of non-neuronal tissues within neural grafts. ${ }^{13} 34$

There has been considerable debate about the extent to which positive results in previous open label transplant studies-in particular in Parkinson's disease, but also in HD-reflect placebo effects when neither the subjects nor the investigators are blind to the experimental condition. The present study is similarly open label, and none of the testing was undertaken blind. Nevertheless, although the present patients with grafts were highly motivated and exhibited clinically strong expectations of success, we saw no evidence for any clear placebo effect when patients were assessed long-term on a well-validated CAPIT test battery, and in spite of expectation of benefit, the patients with grafts exhibited no clear changes on test scores in comparison with the reference control group. Rather, the motor and cognitive features progressed at a very similar rate over the subsequent $8-10$ years in both groups. A similar result has been recorded in an otherwise negative longitudinal clinical trial of riluzole in HD (R Roos, personal communication). Whereas we recognise the need for well-designed double-blind placebocontrolled studies of a candidate cell therapy just like for any 
other medicinal product before it is released for widespread distribution in a standardised format, we consider that placebo effects in open label studies can be overemphasised, and that small case-control studies provide a more efficient and cost effective study format within which to refine and optimise protocols while the methods are still at a relatively early stage of development. ${ }^{35}$.

Although not its primary aim, the present data provide what is probably the longest longitudinal study of functional progression in HD using standardised neurological and neuropsychological tests. For this purpose, both motor and cognitive measures in the UHDRS offered reliable and stable measures of disease progression. All the neurological measures and all but one of the neuropsychological measures yielded a highly significant change across the years, as has been reported previously for non-surgical patients from this cohort over a 3-6-year time span. ${ }^{36}$ While recognising the invalidity of 'concluding the null hypothesis', the very high values for the $\mathrm{F}$ ratios of the main effects of tests (within subjects) increases the impact of the absence of any significant differences over time between the two experimental groups (see tables 4 and 5). The data also attest to the continuing utility of the UHDRS and its subscales as an outcome measure of longitudinal progression in experimental and clinical HD research, although the sensitivity of these measures to detect subtle changes is still unclear. By contrast, whereas some subtests of the CANTAB battery have proved powerful for analysing the precise profile of functional impairment in HD, for instance, with the demonstration of patients particular susceptibility to impairments in extradimensional setshifting, ${ }^{37}$ we found the CANTAB automated touch screen measures to be less sensitive to the longitudinal progression of the disease. A further difference is that it is only on several of the CANTAB subtests that effects of the neurosurgical treatment were seen to show any significant interactions in this trial. However, the significant changes all involved a late-stage deterioration rather than benefit in the group with transplants; and since the effects were restricted only to the last tests applied 810 years post-transplantation, it is not yet clear whether this reflects a stable long-term impairment in specific aspects of prefrontal cognition, or a late-stage decline in individual patients close to the end of their lifespan.

In conclusion, the first five patients in the NEST-UK tolerability and feasibility study of striatal cell transplantation in HD confirms the absence of any long-term adverse effects and, we conclude, based on a limited number of patients followed longterm, that the surgical procedure is itself safe and feasible. Moreover, we found no significant clinical benefit of cell transplantation in these patients in any of the neurological, neuropsychological or imaging assessments. However, as a tolerability trial, we started with a low number of cells implanted, similar to the strategy adopted in dose escalation studies of novel pharmacotherapeutics, and since the imaging revealed no obvious graft masses, the absence of efficacy is not remarkable. To build on these findings, work to establish the optimum tissue selection, preparation and transplantation protocols are now key if efficacy is to be demonstrated. As an adjunct we have followed a group of 12 patients without grafts from the same cohort for more than 10 years, who showed clear and consistent progression of disability over a longer time frame than has been systematically evaluated hitherto. Although conducted as an open label study, it is notable that the patients with grafts showed no evidence whatsoever of a placebo effect, on the basis of which we can conclude that informative pilot data on efficacy can continue to be explored in open label studies with long-term follow-up prior to further refinements in the protocols to a stage where a fully blinded, controlled study is warranted.

\section{Author affiliations}

${ }^{1}$ Cambridge Centre for Brain Repair, Department of Clinical Neurosciences, University of Cambridge, Cambridge, UK

${ }^{2}$ Department of Clinical Neuroscience, University of Cambridge Medical School, Addenbrooke's Hospital, Cambridge UK

${ }^{3}$ Department of Neurosurgery, University of Cambridge Medical School, Addenbrooke's Hospital, Cambridge UK

${ }^{4}$ Department of Psychiatry, University of Cambridge Medical School, Addenbrooke's Hospital, Cambridge UK

${ }^{5}$ Department of Obstetrics and Gynaecology, University of Cambridge Medical School, Addenbrooke's Hospital, Cambridge, UK

${ }^{6}$ Centre for Neuroscience, Division of Experimental Medicine, Department of Medicine, Imperial College London, London, UK

${ }^{7}$ Brain Repair Group, School of Biosciences and Medicine, Cardiff University, Wales, UK

Acknowledgements Thanks to Sonya Foley for her help in an early draft of this paper. We would also like to acknowledge the NIHR support for the Biomedical Research Centre at Addenbrooke's Hospital and the University of Cambridge.

Collaborators The NEST-UK collaboration involved six centres in the Universities of Aberdeen (SA Simpson, J Moore), Belfast (PJ Morrison, TFG Esmonde, N Chada), and Manchester (D Craufurd, J Snowdon, J Thompson), along with Cambridge, Cardiff (P Harper, R Glew, R Harper) and London (as above).

Contributors The following authors were involved in the concept and design of the study: RAB, TPH, BJS, PP, DJB, WC, AER, SBD and the NEST-UK collaboration. The following authors were involved in the acquisition of data: RAB, SLM, TPH, RAS, AKH, MR, ES, TS, HC, AR, TP, SE, CA, YFT, PN, WC, JDP, AER, SBD and the NEST-UK collaboration. The following authors were involved in analysis and interpretation: RAB, SLM, RAS, PP, YFT, DJB, PN, AER, SBD and the NEST-UK collaboration. The following authors were involved in drafting and/or revising the manuscript: RAB, SLM, TPH, RAS, PP, YFT, DJB, PN, WC, AER, SBD

Funding This work was supported by Medical Research Council grant number G9825903, ISRCTN 36485475.

\section{Competing interests None.}

Ethics approval Cambridge Research Ethics Committee.

Provenance and peer review Not commissioned; externally peer reviewed.

Data sharing statement All data relating to this study has been included in the publication. However, where mean values have been reported, the raw data is available upon request to the corresponding author (in anonymised format).

Open Access This is an Open Access article distributed in accordance with the Creative Commons Attribution Non Commercial (CC BY-NC 3.0) license, which permits others to distribute, remix, adapt, build upon this work non-commercially, and license their derivative works on different terms, provided the original work is properly cited and the use is non-commercial. See: http://creativecommons.org/ licenses/by-nc/3.0/

\section{REFERENCES}

1 Ross CA, Tabrizi SJ. Huntington's disease: from molecular pathogenesis to clinical treatment. Lancet Neurol 2011;10:83-98.

2 Cattaneo E, Rigamonti D, Goffredo D, et al. Loss of normal huntingtin function: new developments in Huntington's disease research. Trends Neurosci 2001;24:182-8

3 Tabrizi SJ, Scahill RI, Durr A, et al. Biological and clinical changes in premanifest and early stage Huntington's disease in the TRACK-HD study: the 12-month longitudinal analysis. Lancet Neurol 2011;10:31-42.

4 Leegwater-Kim J, Cha JH. The paradigm of Huntington's disease: therapeutic opportunities in neurodegeneration. Neuro Rx 2004;1:128-38.

5 Foroud T, Gray J, Ivashina J, et al. Differences in duration of Huntington's disease based on age at onset. J Neurol Neurosurg Psychiatry 1999;66:52-6.

6 Bachoud-Levi AC, Remy P, Nguyen JP, et al. Motor and cognitive improvements in patients with Huntington's disease after neural transplantation. Lancet 2000;356:1975-9.

7 Bachoud-Levi AC, Gaura V, Brugieres P, et al. Effect of fetal neural transplants in patients with Huntington's disease 6 years after surgery: a long-term follow-up study. Lancet Neurol 2006:5:303-9.

8 Reuter I, Tai YF, Pavese N, et al. Long-term clinical and positron emission tomography outcome of fetal striatal transplantation in Huntington's disease. J Neurol Neurosurg Psychiatry 2008;79:948-51.

9 Furtado S, Sossi V, Hauser RA, et al. Positron emission tomography after fetal transplantation in Huntington's disease. Ann Neurol 2005:58:331-7. 
10 Gaura V, Bachoud-Levi AC, Ribeiro MJ, et al. Striatal neural grafting improves cortical metabolism in Huntington's disease patients. Brain 2004;127(Pt 1):65-72.

11 Cicchetti F, Saporta S, Hauser RA, et al. Neural transplants in patients with Huntington's disease undergo disease-like neuronal degeneration. Proc Natl Acad Sci U S A 2009:106:12483-8.

12 Hauser RA, Furtado $S$, Cimino CR, et al. Bilateral human fetal striatal transplantation in Huntington's disease. Neurology 2002;58:687-95.

13 Freeman TB, Cicchetti F, Bachoud-Levi AC, et al. Technical factors that influence neural transplant safety in Huntington's disease. Exp Neurol 2011;227:1-9.

14 Wijeyekoon R, Barker RA. The Current Status of Neural Grafting in the Treatment of Huntington's Disease. A Review. Front Integr Neurosci 2011;5:78.

15 Rosser AE, Barker RA, Harrower $T$, et al. Unilateral transplantation of human primary fetal tissue in four patients with Huntington's disease: NEST-UK safety report ISRCTN no 36485475. J Neurol Neurosurg Psychiatry 2002;73:678-85.

16 Directive 2004/23/EC of 31 March 2004, On setting standards of quality and safety for the donation, procurement, testing, processing, preservation, storage and distribution of human tissue and cells. Official J Eur Union 2004;L102:48-58.

17 Rosser AE, Barker RA, Armstrong RJ, et al. Staging and preparation of human fetal striatal tissue for neural transplantation in Huntington's disease. Cell Transplant 2003;12:679-86

18 Peschanski M, Cesaro P, Hantraye P. Rationale for intrastriatal grafting of striatal neuroblasts in patients with Huntington's disease. Neuroscience 1995:68:273-85.

19 Peschanski M, Cesaro P, Hantraye P. What is needed versus what would be interesting to know before undertaking neural transplantation in patients with Huntington's disease. Neuroscience 1996;71:899-900.

20 Torres EM, Fricker RA, Hume SP, et al. Assessment of striatal graft viability in the rat in vivo using a small diameter PET scanner. Neuroreport 1995;6:2017-21.

21 Watts C, Dunnett SB. Towards a protocol for the preparation and delivery of striatal tissue for clinical trials of transplantation in Huntington's disease. Cell Transplant 2000;9:223-34

22 Langston JW, Widner H, Goetz CG, et al. Core assessment program for intracerebral transplantations (CAPIT). Mov Disord 1992;7:2-13.

23 Farrington M, Wreghitt TG, Lever AM, et al. Neural transplantation in Huntington's disease: the NEST-UK donor tissue microbiological screening program and review of the literature. Cell Transplant 2006;15:279-94.
24 Watts C, Donovan T, Gillard JH, et al. Evaluation of an MRI-based protocol for cell implantation in four patients with Huntington's disease. Cell Transplant 2003:12:697-704.

25 Quinn M, Mukhida K, Sadi D, et al. Adjunctive use of the non-ionic surfactant Poloxamer 188 improves fetal dopaminergic cell survival and reinnervation in a neural transplantation strategy for Parkinson's disease. Eur J Neurosci 2008;27:43-52.

26 Huntington Study Group. Unified Huntington's sisease rating scale: reliability and consistency. Mov Disord 1996;11:136-42.

27 Michell AW, Goodman AO, Silva AH, et al. Hand tapping: a simple, reproducible, objective marker of motor dysfunction in Huntington's disease. J Neurol 2008;255:1145-52.

28 Sahakian BJ, Owen AM. Computerized assessment in neuropsychiatry using CANTAB: discussion paper. J R Soc Med 1992;85:399-402.

29 Pavese N, Andrews TC, Brooks DJ, et al. Progressive striatal and cortical dopamine recepto dysfunction in Huntington's disease: a PET study. Brain 2003;126(Pt 5):1127-35.

30 Dunnett SB, Nathwani F, Björklund A. The integration and function of striatal grafts. Prog Brain Res 2000;127:345-80.

31 Watts C, McNamara IR, Dunnett SB. Volume and differentiation of striatal grafts in rats: relationship to the number of cells implanted. Cell Transplant 2000;9:65-72.

32 Gallina P, Paganini M, Lombardini L, et al. Human striatal neuroblasts develop and build a striatal-like structure into the brain of Huntington's disease patients after transplantation. Exp Neurol 2010;222:30-41

33 Keene CD, Chang RC, Leverenz JB, et al. A patient with Huntington's disease and long-surviving fetal neural transplants that developed mass lesions. Acta Neuropathol 2009;117:329-38.

34 Folkerth RD, Durso R. Survival and proliferation of nonneural tissues, with obstruction of cerebral ventricles, in a parkinsonian patient treated with fetal allografts. Neurology 1996;46:1219-15.

35 Boer GJ, Widner H. Clinical neurotransplantation: core assessment protocol rather than sham surgery as control. Brain Res Bull 2002;58:547-53.

36 Ho AK, Sahakian BJ, Brown RG, et al. Profile of cognitive progression in early Huntington's disease. Neurology 2003;61:1702-6.

37 Lawrence AD, Sahakian BJ, Hodges JR, et al. Executive and mnemonic functions in early Huntington's disease. Brain 1996:119(Pt 5):1633-45. 